CARPATHIAN JOURNAL OF FOOD SCIENCE AND TECHNOLOGY

journal homepage: http://chimie-biologie.ubm.ro/carpathian_journal/index.html

\title{
PHYSICAL-CHEMICAL CHARACTERIZATION AND TECHNOLOGICAL AND THERMAL PROPERTIES OF TAMARIND (TAMARINDUS INDICA L.) FROM THE CERRADO OF GOIÁS, BRAZIL
}

\author{
Karen Carvalho Ferreira ${ }^{1 *}$, Márcio Caliari ${ }^{1}$, Juliana Aparecida Correia Bento ${ }^{1}$, Marília Cândido \\ Fideles $^{1}$, Manoel Soares Soares Júnior ${ }^{1}$ \\ ${ }^{1}$ Departament of Agronomy, University Federal of Goiás, Campus Samambaia, Goiânia/Nova Veneza \\ Highway, Km 0, 74690-900, Goiânia, Goiás, Brazil. \\ *karencarvalho1@hotmail.com \\ https://doi.org/10.34302/crpjfst/2019.11.3.9

\begin{tabular}{l} 
Article history: \\
Received: \\
18 February 2018 \\
Accepted: \\
28 March 2019 \\
\hline
\end{tabular} \\ Keywords: \\ Calorimetry, \\ Tamarind pulp, \\ Tamarind seeds, \\ Tamarind shells.

\begin{abstract}
Brazil is a country with different biomes and the Cerrado is known for its rich resources and flora. Among the fruits in the Cerrado, we can highlight the tamarindeiro, whose fruit, tamarind, exhibit excellent nutritional quality. Tamarind is enough explored on the continent of origin (Africa), however surveys involving all utilities of the plant are still insignificant. So, the objective of the work was to characterize shells, pulp and tamarind seeds of the Cerrado, Goiás, as to physico-chemical, technological and thermal properties. The collected fruits obtained average proportions of $22,2 \pm 1,1 \%$ shells, 44,0 $\pm 2,4 \%$ pulp and $14,4 \pm 1,6 \%$ seeds, and approximately $20 \%$ fibers. It presented high carbohydrate content and low water activity for the three portions and lower values of ash, lipids and proteins. The shell and seed flours presented high content of total dietary fiber and fruit pulp presented acid $\mathrm{pH}(3,02 \pm 0,01)$ and high titratable acidity $(29,82 \pm 0,24)$. The seed flour had a water absorption and solubility index greater than the shell flour, and lower oil absorption index. The tamarindo pulp presented 4 peaks in your thermogram, being the first relative to the gelatinization of starch, 2 and 3 peaks suggested the formation of carbohydrate-lipid complexes and protein denaturation and 4 peak the glass transition. Tamarind shell and seed flour showed similar behavior to pulp after $115^{\circ} \mathrm{C}$, with 2 endothermic peaks. Concluded that the integral tamarind fruit has specific physico-chemical, nutritional, thermal and technological characteristics and suitable for use in the food industry.
\end{abstract}

\section{Introduction}

Brazil is a country of great dimensions and with a variety of biomes, of which the Cerrado is included. Considered the second largest Brazilian biome, the Cerrado occupies areas in the states of Goiás, Minas Gerais, Maranhão, Tocantins, Mato Grosso, Mato Grosso do Sul, and portions in other states, and stands out as one of the richest savannahs in the world, one of the Brazilian hotspots. In addition, it presents a lesser known vegetable heterogeneity, which includes numerous exotic fruit species with peculiar sensorial characteristics (Morzelle et al., 2015, Carneiro et al., 2014).

Among the fruit species of the Cerrado of Goiás, the tamarind (Tamarindus indica L.) is found in dispersed plantations without great agroindustrial interest. The tamarind tree is a multifunctional tropical fruit tree grown mainly for its fruits, but all its parts, such as bark, seeds, leaves may offer some benefit because they present nutritional and therapeutic properties 
(Rao, Kumar and Ramana, 2015, Sulieman et al., 2015). Tamarind is characterized by a unique sweet acid taste due to the combination of high levels of tartaric acid and sugars. The fruit has excellent nutritional quality with high levels of carbohydrates, proteins and mineral elements (Adeola and Aworh, 2012, Pereira et al., 2011).

In general, fruits and vegetables are sources of macro, micronutrients and dietary fiber, besides being important natural sources of phytochemical compounds (Yahia, 2010). The consumption of raw fruits and also of its byproducts brings numerous health benefits, contributes to the development of new foods and, consequently, to the recovery of waste from agro-industrial processes, with greater industrial, economic and environmental impacts (Silva et al., 2014).

In the countries of origin, on the African continent, tamarind is widely exploited and valued as a source of sustainable subsistence of cultural, dietary and economic importance. However, the impact of the research involving all utilities of the plant has been insignificant (Adeola and Aworh, 2012). Studies of the properties of fruits and their parts are important for the knowledge of the nutritional value, to add value and quality to the derived products (Paz et $a l ., 2015)$. The production of food from exotic or lesser known fruits and, consequently, their trade and consumption have increased due of their attractive sensory properties and nutritional and therapeutic values (Bicas et al., 2011).

Brazil being a country with great potential and diversified production of fruit, and yet there are several species of these little explored and/or known beyond their regions of origin, which have excellent sensory and nutritional characteristics, the objective of this work was to characterize the tamarind fruit of the Cerrado of Goiás in its pulp, bark and seeds.

\section{Material and methods}

\subsection{Raw material collection and sample preparation}

The fruits were collected in Rio Verde (latitude $\quad 18^{\circ} 01^{\prime} 09,8^{\prime \prime} \mathrm{S}, \quad$ longitude $50^{\circ} 40^{\prime} 17,7^{\prime \prime} \mathrm{W}$ ) and Ceres cities (latitude $15^{\circ} 18^{\prime} 23,7^{\prime \prime}$, longitude 49³6'02,6”W), Goiás state, Brasil, in maturation stage suitable for consumption in the months of August and September 2017, and transported to the Agroindustrial Waste Utilization Laboratory, School of Agronomy of the Federal University of Goiás, in plastic bags at room temperature. The fruits were then selected for the presence of insects and breakdowns and separated manually in shells, pulp and seeds, weighing in a semianalytical balance and calculating the proportions in percentages of whole fruit. The shells and seeds were sanitized in sodium hypochlorite solution $200 \mathrm{ppm}$, dried in an air circulation oven at $40{ }^{\circ} \mathrm{C}$ for 16 hours, then crushed in an industrial blender (Vitalex, LQI02, Catanduva, Brazil), and ground in a cyclone rotor mill (Tecnal, TE65I/2, Piracicaba, Brazil). The tamarind shell and tamarind seed flour were conditioned in bags of high density polyethylene (HDPE) and stored in a freezer at $-18{ }^{\circ} \mathrm{C}$ until the analysis. The tamarind pulps were kept in natura, conditioned and stored under the same conditions as flours until the analysis.

\subsection{Proximal composition and total energy value}

Moisture, ash, protein, lipids and total dietary fiber were determined according to the methods of the Association of Official Analytical Chemistry (2010). Moisture was determined by oven drying with air circulation at $105^{\circ} \mathrm{C}$ until constant weight, ash by weighing after muffle incineration at $550{ }^{\circ} \mathrm{C}$, the nitrogen content by the Kjeldahl method, considering 5,75 as a conversion factor for the calculation of crude protein of vegetable origin, the total lipid content by hot extraction using petroleum ether by the Soxlet method. The dietary fiber was obtained by enzyme-gravimetric method and the total carbohydrate content by difference. All 
analyzes performed in triplicate. The total energy was estimated considering the conversion factors of $4 \mathrm{kcal} \mathrm{g}^{-1}$ for protein and carbohydrate, and $9 \mathrm{kcal} \mathrm{g}^{-1}$ for lipids (Merrill and Watt, 1973).

\subsection{Physical and chemical characterization}

The $\mathrm{pH}$ measurement was determined using a potentiometer (Tecnal, TEC-51, Piracicaba, Brazil), with electrode insertion directly into $5 \mathrm{~g}$ of diluted sample in $100 \mathrm{~mL}$ of water. The total titratable acidity was determined by titration with $\mathrm{NaOH} 0,1 \mathrm{~N}$. The determination of the water activity $\left(\mathrm{a}_{\mathrm{w}}\right)$ was obtained in digital AquaLab (Series 3 TE, Pullman, Washington, USA), of $25^{\circ} \mathrm{C}$. Soluble solids content (SS) was determined using a digital refractometer. All according to the AOAC (2010). The instrumental color parameters ( $\mathrm{L}^{*}, \mathrm{a}^{*}$ and $\mathrm{b}^{*}$ ) were determined in a colorimeter (Bankinh Meter Minolta, BC-10, Ramsey, USA), in which the coordinate $\mathrm{L}^{*}$ expresses the degree of luminosity of the color, $\mathrm{a}^{*}$ the degree of variation between red and green and $b^{*}$ the degree of variation between blue and yellow. The values $a^{*}$ and $b^{*}$ were used to calculate the coordinate $\mathrm{C}^{*}\left(\right.$ chroma $\left.=\left(\mathrm{a}^{2^{*}}+\mathrm{b}^{2^{*}}\right)^{1 / 2}\right)$ and hue angle $\left(\mathrm{H}=\operatorname{tang}^{-1}\left(\mathrm{~b}^{*} / \mathrm{a}^{*}\right)\right.$ ) (Machado et al., 1997). The determination of reducing and total sugar was performed by the 3,5-dinitrosalicylic acid method, according to Miller (1959), with absorbance reading at $540 \mathrm{~nm}$ in the spectrophotometer (Ultrospec, 2.000 UV/Visível, Cambridge, Inglaterra), in aqueous extracts with concentration of $0,2 \mathrm{mg} \mathrm{mL}^{-1}$.

\subsection{Absorption and solubility in water and oil absorption of tamarind shell an seed flours}

The water solubility index (WSI) of the flours was determined according to Anderson et al. (1969). Samples of $2 \mathrm{~g}$ were weighed into centrifuge tubes, added with $30 \mathrm{~mL}$ of distilled water at $25{ }^{\circ} \mathrm{C}$ and shaken on a mechanical stirrer for complete homogenization of the samples. The tubes were placed in a water bath for $30 \mathrm{~min}$ at $28^{\circ} \mathrm{C}$ with shaking and centrifuged for $10 \mathrm{~min}$ at $5300 \mathrm{rpm}(2500 \mathrm{G})$ (Best
Etetronics, TG-WS, Xangai, China). A $10 \mathrm{~mL}$ aliquot of the supernatant was removed and placed in previously tared petri dishes, which remained in an air circulation oven for 2 hours at $105{ }^{\circ} \mathrm{C}$. The plates were weighed and the ISA value was expressed in $g$ of precipitate per $g$ of dry matter. The water absorption index (WAI) of flours equals the weight precipitate in the tube after removal of the supernatant. The result was expressed in $g$ precipitated per $g$ of dry matter.

The oil absorption index (OAI) of the flours was determined according to the methodology described by Castilho, Fontanari and Batistuti (2010). $2 \mathrm{~g}$ of sample was weighed into centrifuge tubes, $10 \mathrm{ml}$ of soybean oil was added and homogenized for $2 \mathrm{~min}$ on mechanical stirrer. Samples were left standing for 15 minutes at $25 \pm 3{ }^{\circ} \mathrm{C}$, and then centrifuged at $8.000 \mathrm{rpm} / 10$ minutes. The volume of the supernatant was measured in graduated cylinder and the OAI was expressed in $\mathrm{ml}$ of absorbed oil per gram of sample.

\subsection{Thermal properties}

The thermal properties of the samples were determined by Differential Scanning Calorimetry (DSC), with calorimeter (TA Instruments, Q20 DCS, New Castle, EUA), based on the methodology described by Weber, Collares-Queiroz and Chang (2009). Samples of $2 \mathrm{mg}$ (b.s) were weighed in aluminum sample port, suitable for DSC equipment. Distilled water $(6 \mu \mathrm{L})$ was added and maintained for $12 \mathrm{~h}$ at $25{ }^{\circ} \mathrm{C}$ to standardize the water distribution. The samples were subjected to a heating cycle of $35-160{ }^{\circ} \mathrm{C}$ the velocity of $10^{\circ} \mathrm{C} \mathrm{min}{ }^{-1}$, and subsequent cooling at the same speed, in order to determine the initial, peak and final temperature, and the enthalpy change $(\Delta \mathrm{H})$ during heating and cooling, according to the manufacturer's manual.

\subsection{Statistical analysis}

Statistical analysis (Statsoft, Statistica 7.0, Tusla, USA) was performed using statistical analysis of variance (ANOVA) and Tukey's test at $5 \%$ of statistical significance. 


\section{Results and discussions}

\subsection{Proportions and proximal composition of fruits}

The collected tamarind fruits had average proportions of $22,2 \pm 1,1 \%, 44,0 \pm 2,4 \%$ e 14,4 $\pm 1,6 \%$ for shell, pulp and seeds, respectively, in relation to the whole fruit. About $20 \%$ of the fruit is the fibers that involve pulp and seeds. The proportions found differ from the averages reported by Pereira et al. (2011) and Favet, Frikart and Potin (2011) which indicated values of approximately $30 \%$ of pulp, $30 \%$ of shell and fibers and $40 \%$ of seeds, as the average of the proportions of tamarinds. The average number of seeds per fruit was 3 seeds, which explains the lower proportion of seeds in relation to the other parts of the fruit. The proportion of pulp was higher than that suggested by Pereira et al. (2011), which can be considered an advantage for fruits of this region, because a higher proportion of pulp in relation to residual fractions are preferred by the industries, as they guarantee a higher processing yield according by Rebouças, Gentil and Ferreira (2008).

The proximal composition and the total energy value are presented in Table 1. The tamarind pulp presented low moisture content when compared to other fruits few explored as Cerrado jatobá (Hymenaea stigonocarpa Mart.)

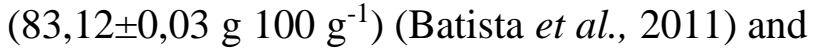
cajarana (Spondias lutea L) $\left(96,1 \pm 0,2{\left.\mathrm{~g} 100 \mathrm{~g}^{-1}\right)}^{-1}\right.$ (Canuto et al., 2010). Evaluating tamarinds from different regions of Nigeria, Adeola and Aworh (2012) found moisture contents in the pulp

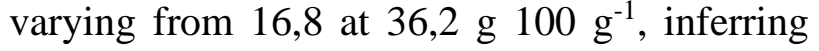
that these variations may occur due to climatic differences and cultivars. Costa et al. (2015)

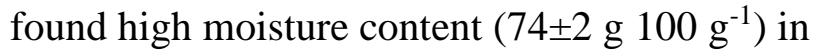

tamarind fruits of the northeast region of Brazil, confirming the variation. Moisture content found in the seed flours of this study is similar to those reported by Mohamed, Mohamed and Ahmed (2015) that found value of 11,21 g 100 g-1 in samples of tamarind seeds. The tamarind shell flour presented the lowest moisture content in relation to the other parts of the fruit, being even smaller than other non-edible fruit shell flours such as passion fruit shell (Cazarin et al., 2014) and banana peel (Gonçalves et al., 2016). Queiroz et al. (2015) evaluated peeling and lychee seed flour finding moisture values of 6,10 and 8,7 g $100 \mathrm{~g}-1$, respectively, being of the larger shells and smaller seeds than the flours of the present study.

The three fractions of the analyzed fruit presented significant difference for verified parameters of ash, lipids, proteins and carbohydrates (Table 1). The values of lipids and proteins were higher in the seed flour, followed by pulp and shell flour. The fact that seeds are better sources of protein when compared to other parts of the fruit can be explained by the storage of their proteins in the concentrated form, since the seeds are nutrient reserve organs (Costa et al., 2015). The presence of lipids is always higher in oilseeds and seeds than in fruits and other vegetables, which have low amounts of this nutrient (Rocha et al., 2008), fact observed in this study. Khairunnuur et al. (2009) studied pulp and tamarind seeds in Malaysia and found ash content of 3,30 and 2,15

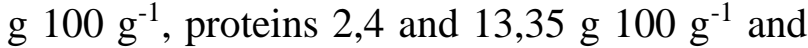
lipids 0,14 and $2,90 \mathrm{~g} 100 \mathrm{~g}^{-1}$, respectively, which are close to the values obtained in this study.

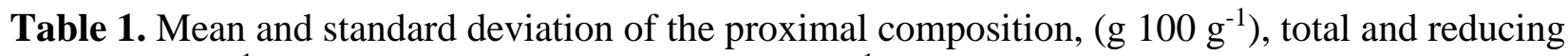
sugars $\left(\mathrm{g} 100 \mathrm{~g}^{-1}\right)$ and total energetic value (kcal $\left.100 \mathrm{~g}^{-1}\right)$ of the "in natura" pulp, tamarind shell flour and tamarind seed flour.

\begin{tabular}{|l|c|c|c|}
\hline \multirow{2}{*}{ Proximal Composition } & \multicolumn{3}{|c|}{ Tamarind (Tamarindus indica L.) } \\
\cline { 2 - 4 } & Pulp & Shell flour & Seeds flour \\
\hline Moisture & $31,22 \pm 0,009 \mathrm{a}$ & $5,96 \pm 0,001 \mathrm{c}$ & $10,20 \pm 0,002 \mathrm{~b}$ \\
\hline Ash & $2,96 \pm 0,004 \mathrm{~b}$ & $3,76 \pm 0,000 \mathrm{a}$ & $2,22 \pm 0,002 \mathrm{c}$ \\
\hline
\end{tabular}




\begin{tabular}{|l|c|c|c|}
\hline Lipids & $0,99 \pm 0,00 \mathrm{~b}$ & $0,54 \pm 0,000 \mathrm{c}$ & $1,77 \pm 0,001^{\mathrm{a}}$ \\
\hline Protein & $4,12 \pm 0,153 \mathrm{~b}$ & $3,22 \pm 0,141 \mathrm{c}$ & $14,56 \pm 0,35^{\mathrm{a}}$ \\
\hline Carbohydrates & $60,71 \mathrm{c}$ & $86,62 \mathrm{a}$ & $71,25 \mathrm{~b}$ \\
\hline Total food fiber & $5,19 \mathrm{c}$ & $70,33 \mathrm{a}$ & $53,89 \mathrm{~b}$ \\
\hline Total sugars & $23,84 \pm 0,50 \mathrm{a}$ & $10,22 \pm 0,82 \mathrm{c}$ & $12,66 \pm 1,59 \mathrm{~b}$ \\
\hline Reducing sugars & $0,25 \pm 0,03 \mathrm{c}$ & $5,60 \pm 0,07 \mathrm{~b}$ & $8,21 \pm 0,09^{\mathrm{a}}$ \\
\hline Total energetic value & $268,23 \mathrm{c}$ & $364,22 \mathrm{a}$ & $359,17 \mathrm{~b}$ \\
\hline
\end{tabular}

* Means followed by the same letter, in the same line, did not differ significantly among themselves by the Tukey test, at $5 \%$ probability.

The integral fruit presented as a good source of carbohydrates, however with different compositions between the fractions (Table 1). The pulp presented higher total soluble sugars, and the shell and seed flours, higher fiber content. The seed flour had the highest concentration of reducing sugars. In the tamarind pulp, the total dietary fiber content was within the value suggested by USDA - United States Department of Agriculture (2009) of 5,1 g $100 \mathrm{~g}^{-1}$. Tamarind shell and seed flours presented high fiber contents when compared to other flours of fruit residues such as lychee shell and seeds flour (Litchi chinensis Sonn) with

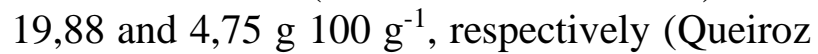
et al., 2015), and the banana caturras peel flour (Musa avendish Lamb.) with total fibers 10,03 g $100 \mathrm{~g}^{-1}$ (Santos et al., 2015). The inclusion of these flours in products can guarantee a greater functionality to these foods because the presence of fiber in the diet helps in regularization of the intestinal transit, giving greater protection to the colonocytes and improving digestion according by Araújo and Menezes (2010).

The total energy value presented by the tamarind fractions reveals a high energy fruit offering $13,4 \%, 18,2 \%$ and $17,9 \%$ of kcal in a $2000 \mathrm{kcal} /$ day diet for pulp, shell and seeds, respectively.

\subsection{Physical-chemical characteristics}

Regarding the chemical characteristics evaluated (Table 2), the pulp, shell and tamarind seeds fractions showed significant differences by Tukey test at $5 \%$ probability.

The $\mathrm{pH}$ found in the tamarind pulp was relatively lower than the $\mathrm{pH}$ of 3,40 found by
Sulieman et al. (2015) in tamarind in the eastern part of Sudan, and higher than that Santos et al. (2016) of 2,75 in a study with frozen tamarind pulps. Low $\mathrm{pH}$ values can guarantee the preservation of fruit pulp without the need for thermal treatment, avoiding nutritional losses and yeast growth (Brasil et al., 2016). The presence of organic acids, important components in the formation of various fruit properties, can also contribute to $\mathrm{pH}$ variation (Santos et al., 2016). Tartaric, malic and citric acids are the main chemical compounds related to tamarind aroma and taste, according to Palomares (2009), being tartaric acid a strong acid, resistant to oxidative respiration, not decreasing with maturation (Pereira et al., 2011; Rizzon and Sganzerla, 2007). The tamarind can be considered a non-climacteric fruit, that is, the respiratory pattern decreases after harvesting, being necessary that the fruit stays in the plant until it is in an optimum state of maturity, which would guarantee more sweet fruits (Chitarra and Chitarra, 2005).

The titratable acidity (TA) presented by the pulp was much higher than in the shell and seed flour, a fact explained by Pereira et al. (2011) due to the large amount of organic acids present in this fruit (12 to 30\% dry matter). Tartaric acid is the main acid present in tamarind pulp and its presence is uncommon in fruits (Hamacek et al., 2013). Thus, TA of the tamarind pulp was expressed in grams of tartaric acid per $100 \mathrm{~g}$ of pulp. Tamarinds from the State of Goiás were similar in terms of TA observed by Sulieman et al. (2015) in tamarinds from Sudan $(28,60 \mathrm{~g}$ tartaric acid $100 \mathrm{~g}^{-1}$ ). 
In the literature, the value of soluble solids (SS) for the tamarind pulp presents great variation. The values found in this study (Table 2) corroborate those verified by Lima et al. (2015) of $7,25^{\circ}$ Brix and by Santos et al. (2016) of 7,70 to $12,58{ }^{\circ}$ Brix, analyzing frozen tamarind pulps. However, they were much lower than the values verified by Sulieman et al. (2015) of 39,9 to $46,6^{\circ}$ Brix and by Canuto et al. (2010) of $24{ }^{\circ}$ Brix. Factors such as climate, irrigation during cultivation and addition of water during the pulp manufacturing process may influence the soluble solids content, which would explain the lack of uniformity between the values presented in different studies (Santos et al., 2016).

The SS/TA ratio is related to the quality of the fruit in terms of maturity and taste, evidencing the balance between sugars and organic acids (Chitarra and Chitarra, 2005). The tamarind pulp showed this reduced relationship, influenced by the high acidity, and it was possible that the fruit was harvested before the optimum ripening stage, which justifies the low soluble solids content.

Shell and tamarind seeds flours showed low water activity (Table 2), and below 0,60 the majority of pathogenic microorganisms do not develop (Forsythe, 2013). The $\mathrm{a}_{\mathrm{w}}$ is a relevant factor in the quality of a food because it influences the speed of reactions, oxidation of lipids, microbial growth, degradation of compounds such as chlorophyll, anthocyanins, besides interfering directly in the perishability of a food (Damodaran, Parkin and Fennema, 2010).

The tamarind fruit, in all its parts, presented reddish-yellow coloration (Figure 1) indicated by the angle value Hue obtained ( $\mathrm{H}$ between 60 70) (Table 3).

Table 2. Mean and standard deviation of the chemical characteristics of the "in natura" pulp, tamarind shell flour and tamarind seed flour.

\begin{tabular}{|c|c|c|c|}
\hline \multirow{2}{*}{ Characteristics } & \multicolumn{3}{|c|}{ Tamarind (Tamarindus indica L.) } \\
\cline { 2 - 4 } & Pulp & Shell flour & Seeds flour \\
\hline $\mathrm{pH}$ & $3,02 \pm 0,01 \mathrm{c}$ & $4,19 \pm 0,02 \mathrm{~b}$ & $5,81 \pm 0,03 \mathrm{a}$ \\
\hline SS $\left({ }^{\circ}\right.$ Brix $)$ & $7,0 \pm 0,1 \mathrm{a}$ & $0,1 \pm 0,1 \mathrm{c}$ & $1,0 \pm 0,1 \mathrm{~b}$ \\
\hline $\begin{array}{c}\text { AT }(\mathrm{g} \text { tartaric } \\
\left.\text { acid } 100 \mathrm{~g}^{-1}\right)\end{array}$ & $29,82 \pm 0,24 \mathrm{a}$ & $6,53 \pm 0,23 \mathrm{~b}$ & $4,26 \pm 0,12 \mathrm{c}$ \\
\hline SS/AT ratio & $0,23 \pm 0,001 \mathrm{a}$ & $0,02 \pm 0,001 \mathrm{~b}$ & $0,23 \pm 0,006 \mathrm{a}$ \\
\hline $\mathrm{a}_{\mathrm{w}}$ & $0,615 \pm 0,01 \mathrm{a}$ & $0,319 \pm 0,001 \mathrm{c}$ & $0,415 \pm 0,002 \mathrm{~b}$ \\
\hline
\end{tabular}

* Means followed by the same letter, in the same line, did not differ significantly among themselves by the Tukey test, at $5 \%$ probability.

Table 3. Mean and standard deviation of the color coordinates $L^{*}, a^{*}, b^{*}, C^{*}$ and Hue angle of the "in natura" pulp, tamarind shell flour and tamarind seed flour.

\begin{tabular}{|l|c|c|c|c|c|}
\hline \multirow{2}{*}{ Tamarind } & \multicolumn{5}{|c|}{ Color coordinates } \\
\cline { 2 - 6 } & $\mathrm{L}^{*}$ & $\mathrm{a}^{*}$ & $\mathrm{~b}^{*}$ & $\mathrm{C}^{*}$ & $\mathrm{H}$ \\
\hline Pulpa & $37,54 \pm 0,35 \mathrm{c}$ & $2,56 \pm 0,44 \mathrm{c}$ & $9,26 \pm 0,52 \mathrm{c}$ & $9,60 \mathrm{c}$ & $74,56 \mathrm{a}$ \\
\hline Shell flour & $54,24 \pm 1,04 \mathrm{~b}$ & $11,35 \pm 0,3 \mathrm{a}$ & $24,22 \pm 0,58 \mathrm{a}$ & $26,75 \mathrm{a}$ & $64,88 \mathrm{c}$ \\
\hline Seeds flour & $64,14 \pm 2,07 \mathrm{a}$ & $7,13 \pm 0,39 \mathrm{~b}$ & $16,12 \pm 0,37 \mathrm{~b}$ & $17,63 \mathrm{~b}$ & $66,13 \mathrm{~b}$ \\
\hline
\end{tabular}

* Means followed by the same letter, in the same column, did not differ significantly from each other by the Tukey test, at $5 \%$ probability. $\mathrm{a}^{*}$ and $\mathrm{b}^{*}$ represent the coordinates of chromaticity $\left(\mathrm{C}^{*}\right)$. The color coordinates were converted to a color angle, $\mathrm{H}=\tan ^{-1 \mathrm{~b} / \mathrm{a}}$ indicating the Hue $(\mathrm{H})$ angle of the sample $\left(0^{\circ}\right.$ or $360^{\circ}=$ red, $90^{\circ}=$ yellow, $180^{\circ}=$ green, $\left.270^{\circ}=\mathrm{blue}\right)$. 


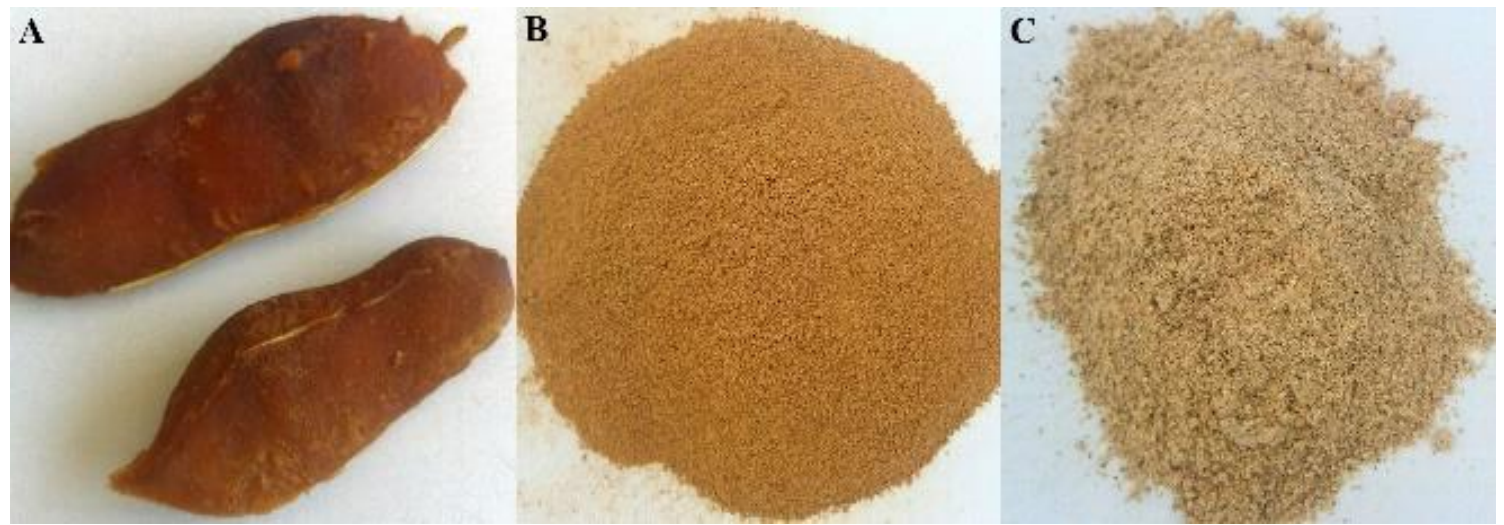

Figure 1. Portions of tamarind (Tamarindus indica L.): (A) Pulp, (B) Flours of the shell, (C) Flours of the seeds.

With respect to the chroma $\left(\mathrm{C}^{*}\right)$, the results indicate that the pulp presents a more opaque coloration, in relation to the other portions. The pulp is characterized as the darkest part, and the seeds the clearest, according to the values of $\mathrm{L}^{*}$

\subsection{Absorption and solubility in water and oil absorption of tamarind shell on seed flours}

The water absorption (WAI) and oil (OAI) and water solubility (WSI) indices of the tamarind bark and seed meal at $28{ }^{\circ} \mathrm{C}$ were evaluated and their results are expressed in Table 4. The flour of tamarind seeds presented higher WAI than the flour of the shells. Increasing the concentration of fiber and protein in flours can raise the rate of water absorption. WAI is a property that is related to the availability of hydrophilic groups in binding to the water molecules, the gel-forming capacity of the starch molecules and the hygroscopic properties of the fibers, which also makes it possible to absorb water (Santillán-Moreno et al., 2011, Filli and Nkama, 2007). Seed flour, even with a lower fiber value than the shell flour, has a protein concentration of 4,5 times higher. Santana, Oliveira Filho and Egea (2017) found in their studies $1,15 \mathrm{~g} \mathrm{~g}^{-1}$ WAI for wheat flour and $4,85 \mathrm{~g} \mathrm{~g}^{-1}$ for passion fruit flour, that is, tamarind shell and seed flours have a greater ability to absorb water than wheat flour, the main raw material in baked goods. This property is important in foods that require hydration and moisture retention as meat products, cakes, found, where values closer to zero approximate black. Canuto et al. (2010) found in their studies values $L^{*}(33,8 \pm 0,5)$ and $H(63,1 \pm 0,2)$ in tamarind pulp, close to the present study, describing the same reddish-yellow coloration.

breads and other baking products improving yield and texture (Porte et al., 2011).

Water solubility index (WSI) was lower in tamarind shell flour when compared to seed flour. The solubility of the flours is related to the amount of water soluble molecules, which can be verified by comparing the water solubility values with the total soluble solids contents of the samples (Ferreira et al., 2015). Santana, Oliveira Filho and Egea (2017) presented WAI values of $15,33 \mathrm{~g} \mathrm{~g}^{-1}$ for flaxseed flour and 10,0 $\mathrm{g} \mathrm{g}^{-1}$ for passion fruit flour, values higher than those found in this study. Flours with high WAI values can be used in foods that require lower temperatures to be prepared as instant and liquid foods or as ingredients for the formulation of soups, desserts and sauces (Santana, Oliveira Filho and Egea, 2017).

The OAI found in the flour of tamarind shells was higher than in the seed flour, however, both presented values higher than the value found by Tril et al. (2014) for tamarind powder extract $\left(1,35 \mathrm{~g} \mathrm{~g}^{-1}\right)$. The ability to absorb oil from a flour may be related to the presence and amount of exposed hydrophobic groups of proteins and their interaction with the hydrophobic chains of fat (Santana, Oliveira 
Filho and Egea, 2017). This is an important parameter of quality because it improves the palatability of the food, in addition to also influencing the emulsifying capacity of a product (Goldmeyer et al., 2014). High oil absorption index determine whether the flour can be used in meat products such as sausages and bologna or emulsified products such as cakes, mayonnaise or sauces (Porte et al., 2011).

Table 4. Mean and standard deviation of the water absorption index (WAI), water solubility (WSI) and oil absorption (OAI) of tamarind shell flour and tamarind seed flour.

\begin{tabular}{|c|c|c|}
\hline \multirow{2}{*}{ Index } & \multicolumn{2}{|c|}{ Tamarind (Tamarindus indica L.) } \\
\cline { 2 - 3 } & Shell flour & Seed flour \\
\hline WAI $\left(\mathrm{g} \mathrm{g}^{-1}\right)$ & $2,43 \pm 0,06$ & $4,17 \pm 0,04$ \\
\hline WSI $\left(\mathrm{g} \mathrm{g}^{-1}\right)$ & $5,19 \pm 0,06$ & $8,19 \pm 0,27$ \\
\hline OAI $\left(\mathrm{mL} \mathrm{g}^{-1}\right)$ & $2,06 \pm 0,03$ & $1,90 \pm 0,02$ \\
\hline
\end{tabular}

\subsection{Thermal properties}

Figures 2,3 and 4 illustrate the DSC graphical analyzes of lyophilized pulp, tamarind shell and tamarind seeds flours, respectively. The thermogram of the pulp (Figure 2), which presented 4 endothermic peaks, was divided into two parts, the first one being from 35 to $105^{\circ} \mathrm{C}$ and the second part from 105 to $155^{\circ} \mathrm{C}$ for better visualization of the peaks. The first peak (Figure 2A) relates to gelatinization of the starch present in the pulp. The initial gelatinization temperature (To) of the tamarind pulp was 69,98 ${ }^{\circ} \mathrm{C} \pm 1,55$, to peak (Tp) was $78,66{ }^{\circ} \mathrm{C} \pm 0,02$ and end $(\mathrm{Te}) 86,61{ }^{\circ} \mathrm{C} \pm 0,57$. The gelatinization temperature range was $16,63{ }^{\circ} \mathrm{C}$ with gelatinization enthalpy $(\Delta \mathrm{H})$ to $3,27 \pm 0,27 \mathrm{~J} \mathrm{~g}^{-}$ 1 . When the available water is restricted, as in the case of lyophilizates, the gelatinization can be delayed at higher temperatures due to the melting of the remaining amylopectin crystals (Moreira, Chenlo and Arufe, 2015).

The 2 peak $\left(101,19{ }^{\circ} \mathrm{C}\right)$ (Figure 2A) and 3 peak $\left(118,51{ }^{\circ} \mathrm{C}\right) \quad$ (Figure 2B) suggest endothermic peaks related to protein denaturation and the formation of amylose-lipid complexes, according to Santiago-Ramos et al., (2018) and Sánchez-Arteaga et al. (2015). The tamarind pulp presents a more complex chemical composition (protein, amylose / amylopectin ratio, minerals, etc.), thus indicating a more complex thermal profile than those reported for isolated starch systems. The presence of two peaks in bands close to temperature may be due to different chemical compounds present (Sánchez-Arteaga et al., 2015). Evaluating the thermal properties of bean flour of different varieties, Sánchez-Arteaga $e t$ al. (2015) found the second endothermic peak between 85 and $105{ }^{\circ} \mathrm{C}$, associated with the presence of heat-resistant proteins. The same peak was observed by Moreira, Chenlo and Arufe (2015) with transition varying between 94,6 and $122,2^{\circ} \mathrm{C}$ for flours of chestnut and corn starch.

The peak number 4 (Figura 2B) suggests the glass transition peak $(\mathrm{Tg})$ of the tamarind pulp which presented a range of $\mathrm{Tg}$, onset: $138,61^{\circ} \mathrm{C}$ to endset: $147,55^{\circ} \mathrm{C}$, and peak $138,85^{\circ} \mathrm{C}$. The $\mathrm{Tg}$ evaluates the temperature at which the sample exits from an amorphous equilibrium state to a rubbery or gummy state, inferring thermal treatments lower than $\mathrm{Tg}$ temperature in the processing of possible products based on lyophilized tamarind pulp. Tg can be used as an indicator of physico-chemical changes in long periods of storage (Alpizar-Reyes et al., 2017).

The tamarind shell and seed flours (Figures 3 e 4) presented similar thermograms after 115 ${ }^{\circ} \mathrm{C}$, with two endothermic peaks and similar behavior to the lyophilized pulp after this temperature, which suggests the same evaluation of the peaks, that is, the peak between 115 and $120^{\circ} \mathrm{C}$ corresponds to the formation of carbohydrate-lipid complexes and/or 
denaturation of proteins and the peak formed approximately at $135{ }^{\circ} \mathrm{C}$ corresponding to the glass transition of the sample. A small peak in the tamarind shell flour thermogram (Figure 3) is also observed at $86,69{ }^{\circ} \mathrm{C}$ for gelatinization.

The endothermic peak of the glass transition to tamarind shell flour had an energy of $18,52 \mathrm{~J}$ $\mathrm{g}^{-1}$ and $\mathrm{Tg}$ of $135,93{ }^{\circ} \mathrm{C}$. In the tamarind seed flour thermogram (Figure 4), is possible check the first peak with To $119,80{ }^{\circ} \mathrm{C}$, Tp $119,94{ }^{\circ} \mathrm{C}$ and Te $120,15^{\circ} \mathrm{C}$. $\mathrm{Tg}$ was observed at $137,92^{\circ} \mathrm{C}$ with transition energy of $23,65 \mathrm{~J} \mathrm{~g}^{-1}$.
The melting temperature of the carbohydrate-lipid complexes is generally high because they have high thermal stability, so the longer the chain length of the complex the greater the physical stability (Kawai et al., 2012). During the thermal sweep of samples of chestnut flour, Ahmed and Al-Attar (2015) detected transitions at various temperatures (104-106 ${ }^{\circ} \mathrm{C}, \quad 114-120{ }^{\circ} \mathrm{C}$ e $135-142{ }^{\circ} \mathrm{C}$ ), associating these transitions to the processes of amylose-lipid complex disorders.
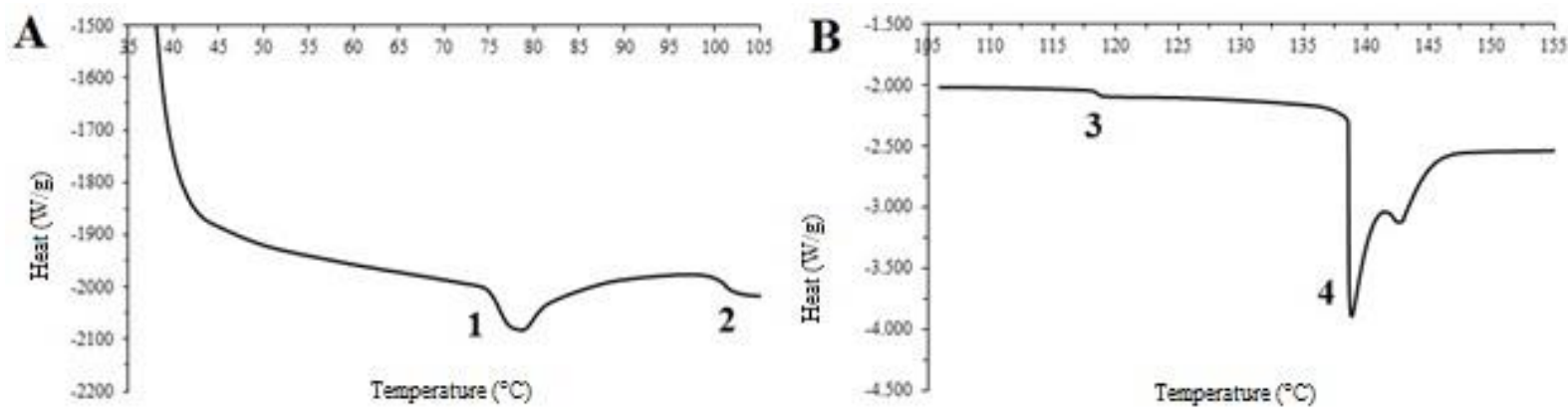

Figure 2. DSC of the freeze-dried tamarind pulp. (A) DSC in the temperature range of 35 to $105^{\circ} \mathrm{C}$, (B) DSC in the temperature range of 105 to $155^{\circ} \mathrm{C}$.

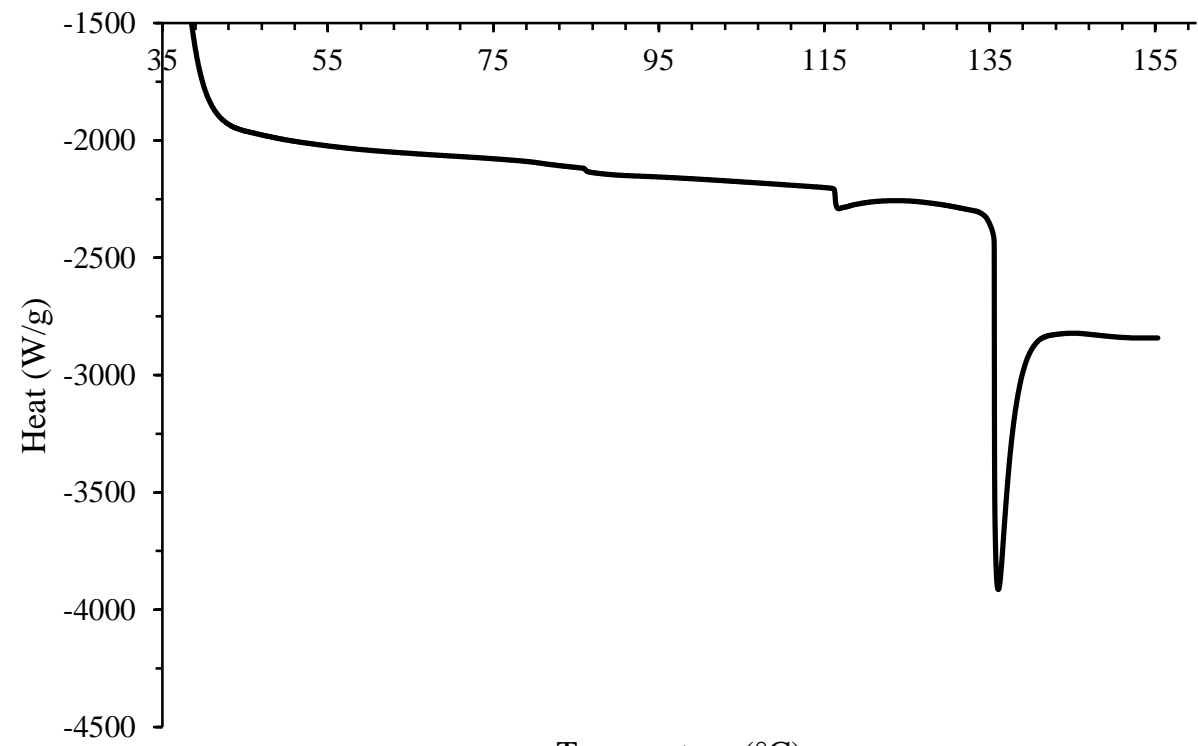

Temperature $\left({ }^{\circ} \mathrm{C}\right)$

Figure 3. DSC of Tamarind shell flour. 


\section{Conclusion}

The tamarind fruit presents excellent physical-chemical and nutritional qualities in all its portions. Flours derived from tamarind shells and seeds are rich in fiber and have technological properties suitable for the food industry, such as instant products such as soups, and even on products that do not require high temperatures. The thermal properties of the tamarind portions suggest a more detailed investigation because they are complex systems.

\section{References}

Adeola, A. A., \& Aworh, O. C. (2012). A comparative evaluation of the chemical properties of wild tamarind (Tamarindus indica L.) fruits in Nigeria. Food, 6(1), 4957.

Ahmed, J., \& Al-Attar, H. (2015). Effect of drying method on rheological, thermal, and structural properties of chestnut flour doughs. Food Hydrocolloids, 51, 76-87.

Alpizar-Reyes, E., Carrillo-Navas, H., GallardoRivera, R., Varela-Guerrero, V., AlvarezRamirez, J., Pérez-Alonso, C. (2017). Functional properties and physicochemical characteristics of tamarind (Tamarindus indica L.) seed mucilage powder as a novel hydrocolloid. Journal of Food Engineering, 209, 68-75.

Anderson, R. A., Conway, H.F., Pfeifer, V. F., Grif-Fn, L. J. (1969). Gelatinization of corn grits by roll and extrusion cook. Cereal Science Today, 14(1), 4-11.

Araújo, E. M., Menezes, H. C. (2010). Study of dietary fibre in fruits and vegetables for use in oral or enteral diets. Food Science and Technology, 30(1), 42-47.

AOAC - Association of Official Analytical Chemists. (2010). Official methods of Analysis. (18 $\mathrm{a}$ ed.). Washington: DC USA.

Batista, A. G., Esteves, E. A., Dessimoni-Pinto, N. A. V., Oliveira, L. G., Pires, S. T., Santana, R. C. (2011). Chemical composition of jatobá-do-cerrado
(Hymenaea Stigonocarpa Mart.) flour and its effect on growth of rats. Alimentos $e$ Nutrição, 22(2), 173-180.

Bicas, J. L., Molina, G., Dionísio, A. P., Barros, F. F. C., Wagner, R., Maróstica Junior, M. R., Pastore, G. M. (2011). Volatile constituents of exotic fruits from Brazil. Food Research Internacional, 44(7), 18431855.

Brasil, A. S., Sigarini, K. S., Pardinho, F. C., Faria, R. A. P. G., Siqueira, N. F. M. P. (2016). Evaluation of physicochemical quality of frozen fruit pulp marketed in the city of Cuiabá-MT. Revista Brasileira de Fruticultura, 38(1), 167-175.

Canuto, G. A. B., Xavier, A. A. O., Neves, L. C., Benassi, M. T. (2010). Physical and chemical characterization of fruit pulps from Amazonia and their correlation to free radical scavenger activity. Revista Brasileira de Fruticultura, 32(4), 1196-1205.

Carneiro, V. A., Gomes, H. B., Nasser, M. D., Resende, H. G. (2014). O Baru (Dipteryx alata Vog.) como exemplo de incremento de renda e de sustentabilidade de comunidades rurais no cerrado goiano: um relato de experiência via seminários da disciplina "Sistemas Agrários de Produção e Desenvolvimento Sustentável”. Revista InterAtividade, 2(2), 42-52.

Castilho, F., Fontanari, G. G., Batistuti, J. P. (2010). Evaluation of some functional properties of lupin sweet flour (Lupinus albus) and faba bean flour (Cajanus cajan (L) Millsp) and their utilization in cooked ham production. Food Science and Technology, 30(1), 68-75.

Cazarin, C. B. B., Silva, J. K. d., Colomeu, T. C., Zollner, R. d. L., Maróstica Junior, M. R. (2014). Antioxidant capacity and chemical composition of passion fruit peel (Passiflora edulis). Ciência Rural, 44(9), 1699-1704.

Chitarra, M. I. F., Chitarra, A. B. (2005). Póscolheita de frutas e hortaliças: fisiologia e manuseio. (2nd ed). Lavras: UFLA.

Costa, W. D., Loiola, L. C. O., Nonato, C. F. A., Andrade, C. C., Costa, J. G. M., Rodrigues, 
F. F. G. (2015). Physicochemical, bromatological and antibacterial analysis of Tamarindus indica Linn fruits. Caderno de Cultura e Ciência, 14(1), 86-95.

Damodaran, S., Parkin, K. L., Fennema, O, R. (2010). Química de alimentos de Fennema. ( $4^{\mathrm{a}}$ ed.) Porto Alegre: Artmed.

Favet, R., Frikart, M.-J., Potin, J. (2011). La valorisation $\mathrm{du}$ tamarin. Richesses et potentialités des agroressources dans les PED UE 9 - IAAS 3. Montpellier SupAgro.

Ferreira, M. S. L., Santos, M. C. P., Moro, T. M. A., Basto, G. J., Andrade, R. M. S., Gonçalves, É. C. B. A. (2015). Formulation and characterization of functional foods based on fruit and vegetable residue flour. Journal of Food Science and Technology, 52(2), 822-830.

Filli, K. B., Nkama, I. (2007). Hydratation properties of extruded fura from millet and legumes. British Food Journal, 109(1), 6880.

Forsythe, S. J. (2013). Microbiologia de segurança dos alimentos. (2nd ed.) Porto Alegre: Artmed.

Goldmeyer, B., Penna, N. G., Melo, A., Rosa, C. S. (2014). Physicochemical characteristics and technological functional properties of fermented blueberry pomace and their flours. Revista Brasileira de Fruticultura, 36(4), 980-897.

Gonçalves, J. Q., Silva, M. A. P. d., Plácido, G. R., Caliari, M., Silva, R. M., Moura, L. C., Souza, D. G. (2016). Drying kinetics of green banana peel and pulp (musa acuminata): properties physical and functional of flour. Global Science and Technology, 9(3), 62-72.

Hamacek, F. R., Santos, P. R. G., Cardoso, L. d. M., Pinheiro-Sant'Ana, H. M. (2013). Nutritional composition of tamarind (Tamarindus indica L.) from the Cerrado of Minas Gerais, Brazil. Fruits, 68(5), 381-395.

Kawai, K., Takato, S., Sasaki, T., Kajiwara, K. (2012). Complex formation, thermal properties, and in-vitro digestibility of gelatinized potato starch-fatty acid mixtures. Food Hydrocolloids, 27(1), 228234.

Khairunnuur, F. A., Zulkhairi, A., Azrina, A., Moklas, M. A. M., Khairullizam, S., Zamree, M. S., Shahidan, M. A. (2009). Nutritional composition, in vitro antioxidant activity and artemia salina 1. Lethality of pulp and seed of Tamarindus indica L. extracts. Malaysian Journal of Nutrition, 15(1), 65-75.

Lima, T. L. S., Cavalcante, C. L., Sousa, D. G., Silva, P. H. A., Sobrinho, L. G. A. (2015). Evaluation of physical and chemical composition of fruit pulp marketed in five cities in the Paraiba state-Brazil. Revista Verde, 10(2), 49-55.

Machado, P. P., Hotza, D., Petter, C., Bergmann, C. P. (1997). Controle de qualidade para revestimentos cerâmicos através da análise colorimétrica de superfície vidrada monocromática. Cerâmica Industrial, 2(3/4) 51-5.

Merrill, A. L., Watt, B. K. (1973). Energy value of foods: basis and derivation. DC: United States Department of Agriculture, Washington.

Miller, G. L. (1959). Use of dinitro salicylic acid reagent for determination of reducing sugar. Analytical Chemistry, 31(3), 426-8.

Mohamed, H., Mohamed, B. E., Ahmed, K. E. (2015). Physicochemical properties of tamarind (Tamarindus indica) seed polysaccharides. Journal of Food Processing Technology, 6(6), 1-5.

Moreira, R., Chenlo, F., Arufe, S. (2015). Starch transitions of different gluten free flour doughs determined by dynamic thermal mechanical analysis and differential scanning calorimetry. Carbohydrate Polymers, 127, 160-7.

Morzelle, M. C., Bachiega, P., Souza, E. C. D., Vilas Boas, E. V. D. B., \& Lamounier, M. L. (2015). Chemical and physical charecterization of fruits from Cerrado: curriola, gabiroba and murici. Revista Brasileira de Fruticultura, 37(1), 96-103. 
Okezie, B. O., Bello, A. B. (1988). Physicochemical and functional properties of winged bean flour and isolate compared with soy isolate. Journal of Food Science, 53(2), 450-4.

Palomares, S. G. (2009). Determination of aromatic compounds in tamarind (Tamarindus indica L.) by two methods of extraction. Unacar Tecnociencia, 3(2), 2939.

Paz, M., Gúllon, P., Barroso, M. F., Carvalho, A. P., Domingues, V. F., Gomes, A. M., Becker, H., Longhinotti, E., Matos, C. D. (2015). Brazilian fruit pulps as functional foods and additives: Evaluation of bioactive compounds. Food Chemistry, 172(1), 462-8.

Pereira, P. C., Melo, B., Franzão, A. A., Alves, P. R. B. (2011). A cultura do tamarindeiro (Tamarindus indica L.). Universidade Federal de Uberlândia. In: $<$ http://www.fruticultura.iciag.ufu.br./tamar indo.htm>. Acess: 07/26/2016.

Porte, A., Silva, E. F., Almeida, V. D. S. Silva, T. X., Porte, L. H. M. (2011). Technological functional properties of papaya (Carica papaya) and pumpkins (Cucurbita sp) seed flours. Revista Brasileira de Produtos Agroindustriais, 13(1), 91-6.

Queiroz, E. R., Abreu, C. M. P., Santos, C. M., Simão, A. A. (2015). Chemical and phytochemical composition of flours from skin and seeds of 'Bengal' lychee (Litchi chinensis Sonn). Ciência Rural, 45(2), 329334.

Rao, A. S., Kumar, A. A., Ramana, M. V. (2015). Tamarind seed processing and byproducts. Agricultural Engineering International: CIGR Journal, 17(2), 200-4.

Rebouças, E. R., Gentil, D. F. O., Ferreira, S. A. N. (2008). Physical characterization of fruits and seeds of Costa Rican guavas produced in Manaus, Amazonas. Revista Brasileira de Fruticultura, 30(2), 546-8.

Rizzon, L. A., Sganzerla, V. M. A. (2007). Tartaric and malic acids in the must grapes of Bento Gonçalves-RS, Brazil. Ciência Rural, 37(3), 911-4.
Rocha, S. A., Lima, G. P. P., Borguini, M. G., Ciccone, V. R., Beluta, I. (2008). Fiber and lipid in plant food from organic and conventional farming. Revista SimbioLogias, 1(2), 1-9.

Sánchez-Arteaga, H. M., Urias-Silvas, J., Espinosa-Andrews, H., García Márquez, E. (2015). Effect of chemical composition and thermal properties on the cooking quality of common beans (Phaseolus vulgaris). CyTA - Journal of Food, 13(3), 385-391.

Santana, G. S., Oliveira Filho, J. G. d., Egea, M. B. (2017). Characteristics technological of commercial vegetable flours. Revista de Agricultura Neotropical, 4(2), 88-95.

Santiago-Ramos, D., Figueroa-Cárdenas, J. d. D., Véles-Medina, J. J., Salazar, R. (2018). Physicochemical properties of nixtamalized black bean (Phaseolus vulgaris L.) flours. Food Chemistry, 240, 456-462.

Santillán-Moreno, A., Martínez-Bustos, F., Castaño-Tostado, E., Amaya-Llano, S. L. (2011). Physicochemical characterization of extruded blends of corn starch-whey protein concentrate-Agave tequilana fiber. Food Process and Biotechnology, 4(1), 797-808.

Santos, L. F., Lehner, M. T., Freitas, A. F. F., Ries, E. F. (2015). Caturra banana flour characterization and use in dietary cookie. Magistra, 27(2), 145-158.

Santos, E. H. F., Figueiredo Neto, A., Donzeli, V. P. (2016). Physical, chemical and microbiological aspects of fruit pulps marketed in Petrolina (PE) and Juazeiro (BA). Brazilian Journal of Food Technology, 19, 1-9.

Silva, L. M. R. d., Figueiredo, E. A. T. d., Ricardo, N. M. P. S., Vieira, I. G. P., Figueiredo, R. W. d., Brasil, I. M., Gomes, C. L. (2014). Quantification of bioactive compounds in pulps and by-products of tropical fruits from Brazil. Food Chemistry, 143, 398-404.

Sulieman, A. M. E., Alawad, S. M., Osman, M. A., Abdelmageed, E. A. (2015). Physicochemical characteristics of local varieties of tamarind (Tamarindus indica $\mathrm{L}$ ), 
Sudan. International Journal of Plant Research, 5(1), 13-8.

Tril, U., Fernández-López, J., Álvarez, J. Á. P., Viuda-Martos, M. (2014). Chemical, physicochemical, technological, antibacterial and antioxidant properties of rich-fibre powder extract obtained from tamarind (Tamarindus indica L.). Industrial Crops and Products, 55, 155-162.

USDA - United States Department of Agriculture. (2009). USDA National Nutrient Database for Standard Reference. (22. ed.).

Weber, F. H., Collares-Queiroz, F. P., Chang, Y. K. (2009). Physicochemical, rheological, morphological, and thermal characterization of normal, waxy, and high amylose corn starches. Food Science and Technology, 29(4), 748-753.

Yahia, E. M. (2010). The contribution of fruit and vegetable consumption to human health. In: Rosa, L.A., Alvarez-Parrilla, E., Gonzalez-Aguilara, G.A. Fruit and vegetable phytochemicals: chemistry, nutritional value and stability. (pp. 3-51). Hoboken: Wiley-Blackwell.

\section{Acknowledgement}

The authors are grateful for the financial support of CAPES - Coordination for the Improvement of Higher Education Personnel 